\title{
Radiometric Mapping for Naturally Occurring Radioactive Materials (NORM) Assessment in Mamuju, West Sulawesi
}

\author{
H. Syaeful ${ }^{\star}$, I.G. Sukadana and A. Sumaryanto \\ Center for Nuclear Minerals Technology, National Nuclear Energy Agency \\ Jl. Lebak Bulus Raya No. 49, Jakarta 12440, Indonesia
}

\section{ARTICLE INFO}

\section{Article history:}

Received 08 November 2013

Received in revised form 20 February 2014

Accepted 10 March 2014

\section{Keywords:}

NORM

Mamuju

Thorium

Uranium

Radiometric

\begin{abstract}
A B S T R A C T
Mamuju has been known to have high radiation dose rate which comes from NORM in rock and soil. Major concern is due to its location which is near inhabitant settlement area. Preliminary research has been done by environmental team which is limited to main access road only, while some remote area has left untouched. The purpose of the research is to delineate the location and distribution of thorium and uranium anomaly in Mamuju, and also to provide adequate information regarding the anomaly and high dose rate area to decision makers and stakeholders in neither local nor central government. Method applied is radiometric mapping using spectrometer RS-125 with $\mathrm{NaI}(\mathrm{Tl})$ detector in the area of interest Geological Formation of Adang Volcanic, which is more than 800 square $\mathrm{km}$ in size. The radiometric mapping method is widely used in uranium/thorium exploration, and now has been added with the measurement of radiation dose rate which is appropriate to environmental surveys. The mapping has been successfully delineated the area of NORM or the area with thorium and uranium anomaly. Thorium and uranium anomaly are related with multi-geological-process resulting the increase of grade into several fold from its original state.
\end{abstract}

\section{INTRODUCTION}

Mamuju has been reported for its high radiation dose rate due to its natural uranium content. Started from 2007 when Iskandar et al. (2007) [14] released the Gamma Dose Rate Map of Indonesia. On that map, Mamuju shows the highest average dose rate compared to other region in Sulawesi and even Indonesia, which can achieved $2,800 \mathrm{nSv} / \mathrm{h}$. The dose rate measurement conducted by carborne-radiometric using portable gamma ray spectrometer of Exploranium GR-130 in main road network of Sulawesi and other island of Indonesia. In 2012, Mamuju radioactivity has been brought to media and reaches wider communities. However, the news often does not reflect actual natural conditions of Mamuju.

Radiometric mapping are very popular, practical, and effective method for thorium/uranium anomaly detection. Basically, the method measures the abundance of potassium, thorium, and uranium of the Earth's surface, which is NORM. Other use of radiometric mapping are also described by Bahiru et al., (2011) [2] and Elawadi et al., (2008) [8] for

\footnotetext{
* Corresponding author.

E-mail address:syaeful@batan.go.id
}

regolith and surface mapping, Bassey et al., (2012) [3] and Anonymous (2009) [9] for lithologic mapping, Graaf et al., (2006) [10] for sediment contamination, Dantas et al., (2003) [6] for structural geology analysis, and Coetzee \& Larkin (2009) [5] for radiation protection.

The purpose of the study is finding the thorium and uranium anomaly and also describe the location, distribution, and size distribution of Naturally Occurring Radioactive Materials (NORM) based on radioelement map, radioelement ratio map, and dose rate map. Moreover, to give guide to other stakeholder regarding the location of high radiation dose rate in Mamuju.

\section{EXPERIMENTAL METHODS}

According to IAEA (2003) [12], Naturally Occurring Radioactive Materials (NORM) comprises radioelements associated with the $238 \mathrm{U}$ and $232 \mathrm{Th}$ decay chains as well as $40 \mathrm{~K}$. These radioelements are very long lived and have some progeny that are long lived, such as $226 \mathrm{Ra}$ for example, in the Uranium series. The distribution of radioelements in the geosphere depends on the distribution of the geological media from which 
they are derived and the processes which concentrate them at a specific location in specific media. Amadi (2012) [1] explicate that the origin of radioactive elements in rocks is linked directly with the crystallization of magma. Radioactive elements do not readily combine with silicate minerals in the melt, rather they are deposited by residual fluid of a magmatic upsurge.

According to IAEA (2003) [11] most of the gamma rays emanating from the earth's surface originate in the top $30 \mathrm{~cm}$ of the earth. This means that the interpretation of these data require an understanding of surface processes such as weathering, and the relationship between surficial materials and bedrock geology. In radiometric mapping, disequilibrium in the $U$ decay series is a serious source of error. Estimates of $U$ concentrations are based on the assumption of equilibrium conditions, and this is not necessarily the case. The conventional approach to the acquisition and processing of gamma ray spectrometric data is to monitor three or four relatively broad spectral windows (Fig. 1, Table 1). The $\mathrm{K}$ energy window monitors the $1.46 \mathrm{MeV}$ gamma rays emitted by $40 \mathrm{~K}$. The $U$ and Th energy windows monitor gamma ray emissions of decay products in the $\mathrm{U}$ and $\mathrm{Th}$ decay series. These windows are generally accepted as the most suitable for the measurement of $\mathrm{K}, \mathrm{U}$ and $\mathrm{Th}$. The total-count window gives a measure of total radioactivity.

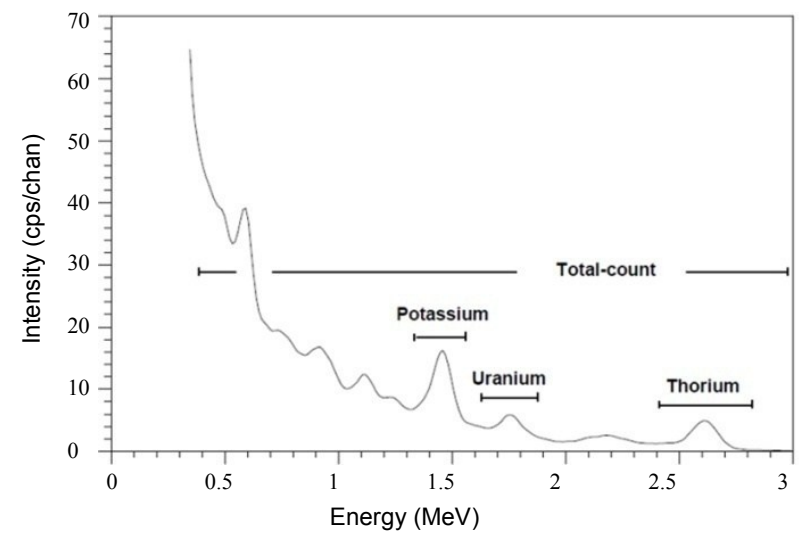

Fig. 1. Typical gamma ray spectrum showing the positions of the conventional energy windows (IAEA, 2003) [11].

Table 1. Standard gamma ray energy windows recommended for natural radioelement mapping (IAEA, 2003) [11].

\begin{tabular}{ccc}
\hline Window & Nuclide & $\begin{array}{c}\text { Energy Range } \\
(\mathrm{MeV})\end{array}$ \\
\hline Total Count & - & $0.400-2.810$ \\
\hline Potassium & ${ }^{40} \mathrm{~K}(1.460 \mathrm{MeV})$ & $1.370-1.570$ \\
\hline Uranium & ${ }^{214} \mathrm{Bi}(1.765 \mathrm{MeV})$ & $1.660-1.860$ \\
\hline Thorium & ${ }^{208} \mathrm{Tl}(2.614 \mathrm{MeV})$ & $2.410-2.810$ \\
\hline
\end{tabular}

\section{Environmental effects}

IAEA (2003) [11] described guide on diminish the environmental effects during field measurement. The existing of attenuating material between the radioactive source and the gamma raydetector affects the measured radiation. Nonradioactive overburden such as soil, vegetation, water, can significantly reduce the radiation output from the earth's surface. Changing temperatures and pressures can lead to a change in air density by up to 30 percent. Soil moisture can be a significant source of error in gamma ray surveying. An increase in soil moisture of 10 percent will decrease the measured effluence rate by about the same amount. Precipitation can have a large effect on uranium estimation. Daughter products of airborne radon attach themselves to dust particles in the atmosphere. The radioactive precipitation of these particles by rain can lead to apparent increases of more than 2000 percent in uranium ground concentrations. Gamma ray surveying should therefore not be carried out during rainfall or shortly thereafter. About three hours is required for the anomalous surface activity to decay away.

\section{Instrumentation}

Portable hand-held gamma ray spectrometers are widely used in field studies. Portable threshold spectrometers have up to $100 \mathrm{~cm}^{3}$ of $\mathrm{NaI}(\mathrm{Tl})$ crystals as detectors, and several switch-operated energy thresholds. The threshold can be set to a low energy for total count measurement, and to energies slightly below $1.46 \mathrm{MeV}, 1.76 \mathrm{MeV}$ and $2.62 \mathrm{MeV}$ for $\mathrm{K}, \mathrm{U}$, and $\mathrm{Th}$ measurement, respectively. A reference gamma ray emitting source is used for instrument gain adjustment. Threshold spectrometers with small crystal volumes are suitable for crude spot measurements of total count anomalies.

The device used in survey is spectrometer Radiation Solution - 125. RS-125 device uses the same method as listed above, using $103 \mathrm{~cm}^{3}$ Thalium doped Sodium Iodide or NaI(Tl) detector which capable to read $\mathrm{K}, \mathrm{U}$, Th, dose rate, and total count (TC) in every measurement. It is also can be directly linked to Bluetooth Global Positioning System which can provide coordinate information during field measurement.

\section{RESULTS AND DISCUSSION}

\section{Geological formation}

Geologically, the area with the high radiation dose rate can be localized in geological Formation 
of Adang Volcanic. Ratman and Atmawinata (1993) [16] concluded that the formation mainly composed by extrusive volcanic product, which is mafic rock of leucite basaltic tuff, lava and volcanic breccias. In the east, Formation of Talaya Volcanic is intermediate extrusive volcanic product (Fig. 2). In more detail geological mapping during radiometric measurement, the Formation of Adang Volcanic composed by feldsphatoid lava rock, pyroclastic, tuffities, and granite.

Generally, compared to Adang Volcanic Formation, the Talaya Formation has significant lower dose rate. In the southern boundary of Geological Formation in the area of Taan village, the radiation dose rate drop from approximately $400 \mathrm{nSv} / \mathrm{h}$ in Adang Volcanic to $100 \mathrm{nSv} / \mathrm{h}$ in Talaya Volcanic. In northern boundary, the dose rate slightly decreases from in the order of 250 to $200 \mathrm{nSv} / \mathrm{h}$. In the north of Formation in Kaluku District, lithology in Adang Volcanic Formation was not the feldsphatoid rock as it dominant, nevertheless it is tuffaceous quartz sandstone.

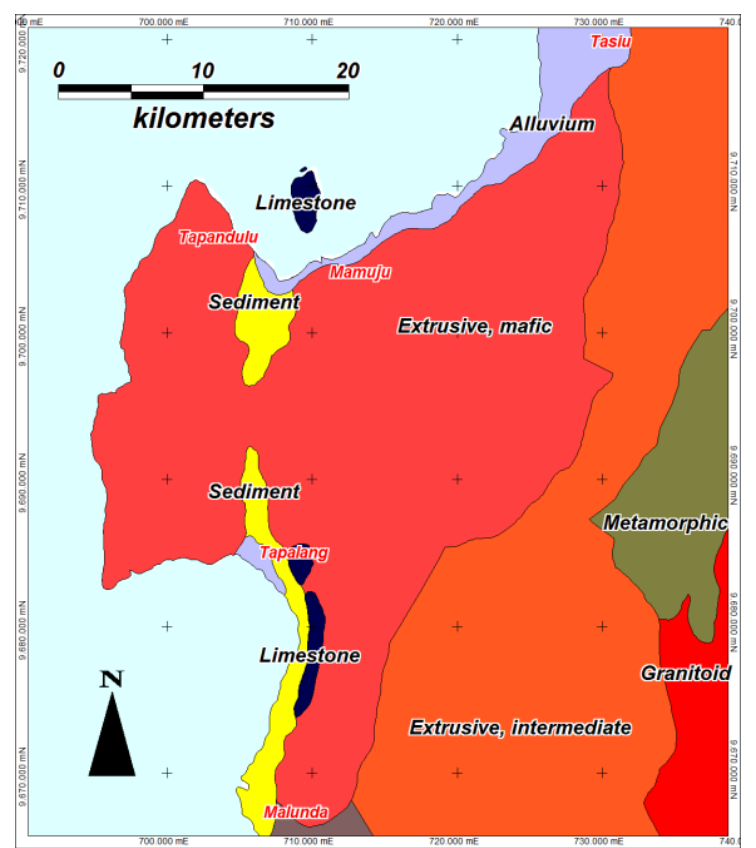

Fig. 2. Geological formation of Mamuju and its surrounding [16].

On the volcano geomorphology aspect, refer to Thouret (1999) [17] classification, Mamuju interpreted as polygenetic volcanoes and calderas type with stratovolcanoes sub-type. From Shuttle Radar Topography Mission (SRTM) image (Fig. 3) the sector collapse scar identified in central part of Adang Volcanic Formation which is the upstream of Mamuju river. The slope in the Adang Volcanic Formation is in semi steep to steep or averaged 5 to $30 \%$. Apart some flat slope also occur in the alluvium deposit such as in Mamuju city.

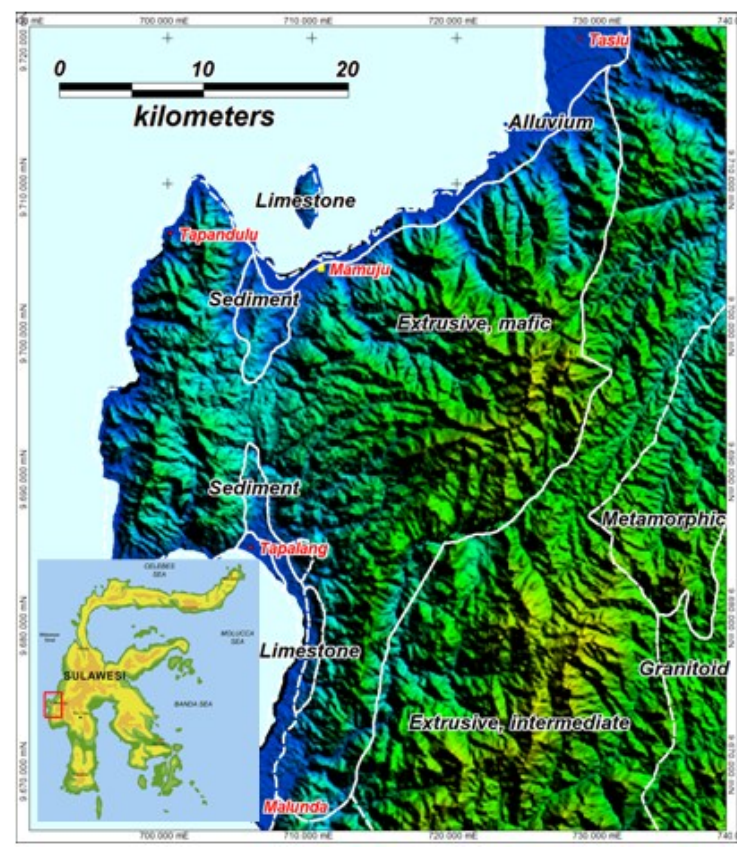

Fig. 3. SRTM image of Mamuju and its surrounding.

\section{Data collection}

Since thorium and uranium are related with the disequilibrium aspect, and the measurement method using disintegration gamma ray emission from radioelement daughter, then the result of measurement begins with code of equivalent (e). Field measurement conducted by dynamic and static method. The dynamic method conducted by setting the RS-125 radiometric device to automatically stored data in every 1 or 3 minutes depend on area of interest. In the low radiometric area in the lithology of volcano sedimentary such as in Dungkait, Labuhan Rano, Sumare in western part of Mamuju the recording set to 3 minutes or $\pm 90 \mathrm{~m}$ data interval, while in medium to high radiometric area recording time set to 1 minute or $\pm 30 \mathrm{~m}$ data interval such as in Takandeang, Ahu, and Botteng village. In order to keep the consistency in measurement, the device height above ground is kept to 1 meter. In favor of radiation dose rate purpose, this kind of measurement will reflect the actual radiation emission to human instead of adhered it to surface measurement such as in static method. Nearly 6,000 measurement collected, representing the general regional radiometric situation of Adang Volcanic Formation. Due to very broad the area of Adang Volcanic Formation which is achieved 820 square $\mathrm{km}$, the spacing of survey line varies from around $1 \mathrm{~km}$ to $5 \mathrm{~km}$ or can be categorized as wide space survey.

Data of measurement consist of radiation dose rate, potassium $(\mathrm{K})$, thorium $(\mathrm{Th})$, uranium (U). The radiation dose rate varies between 35 to 
11,265 with average of $607 \mathrm{nSv} / \mathrm{h}$. Potassium between 0 to 18 with average $2 \%$. Uranium between 0 to 1,529 with average $25 \mathrm{ppm}$ eU. Thorium between 1 to 817 with average $127 \mathrm{ppm}$ eTh. For analyzing the range between class of data in contour thematic map of each radioelement and dose rate, the data are iterated as shown in Fig. 4.
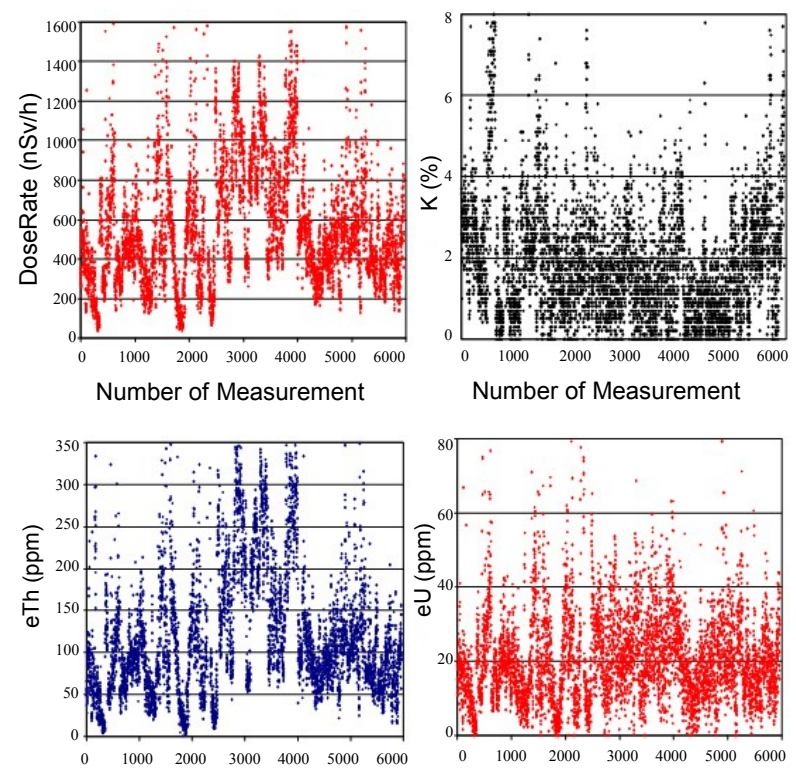

Fig.4.Scattered measurement data of Dose Rate, K,U and Th.

\section{Radioelement concentration and radioelement ratio map}

Refer to IAEA (2003) [13] the abundance of potassium in the Earth's upper crust is 2.33 wt. \% K. Most $\mathrm{K}$ occurs as alkali feldspar and micas in felsic rocks, mainly granitoids, which contain 3.5 wt. $\% \mathrm{~K}$ on average. Mafic and ultramafic rocks contain much lower concentrations. The feldspar mineral series, the feldspathoids leucite and nepheline, and the micas biotite and muscovite, together contain virtually all the potassium in metamorphic and magmatic rocks. The feldsphatoid rocks with leucite are the dominant rock in Mamuju, which make the rocks in Mamuju generally high in potassium content.

All maps are made with $0.4 \mathrm{~km}$ grid cell with $4 \mathrm{~km}$ searching radius using inverse distance weighting method with average method (moving average gridding) for data influence interfere. Radiometric map of potassium dominantly shows the low to medium $\mathrm{K}(0-6 \%)$, while the high $\mathrm{K}(6-8 \%)$ shown in eruption center or in sector collapse scar of Adang Volcanic. The radiometric map of potassium uniquely differ the lithology in eruption center with other part of Formation (Fig. 5).

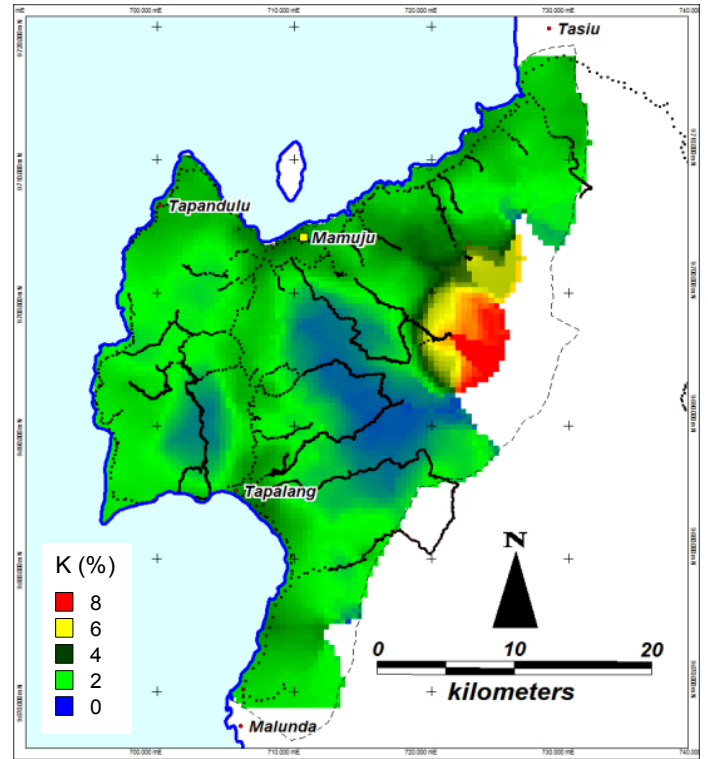

Fig. 5. Radioelement map of Potassium (K).

Bea, 1999 in IAEA (2003) [11] stated that uranium is a reactive metal with an average abundance of about $3 \mathrm{ppm}$ in the Earth's crust. U appears in the valence state $\mathrm{U}^{4+}$ in igneous rocks with crystallochemical properties close to $\mathrm{Th}^{4+}$ and the Light Rare Earth Elements (LREE), which explains the coherent geochemistry of $\mathrm{U}, \mathrm{Th}$ and LREE in igneous rocks. From the result of field measurement (Fig. 6), generally known that uranium has enriched from its crustal abundance of $3 \mathrm{ppm}$. In the meantime, the highest uranium content measurement found in Botteng (red). Some other area are also found to be relatively high in uranium such as upstream of Ampalas river, Tande-tande village, and Salunangka village, nevertheless in those place the anomaly area was not really wide.

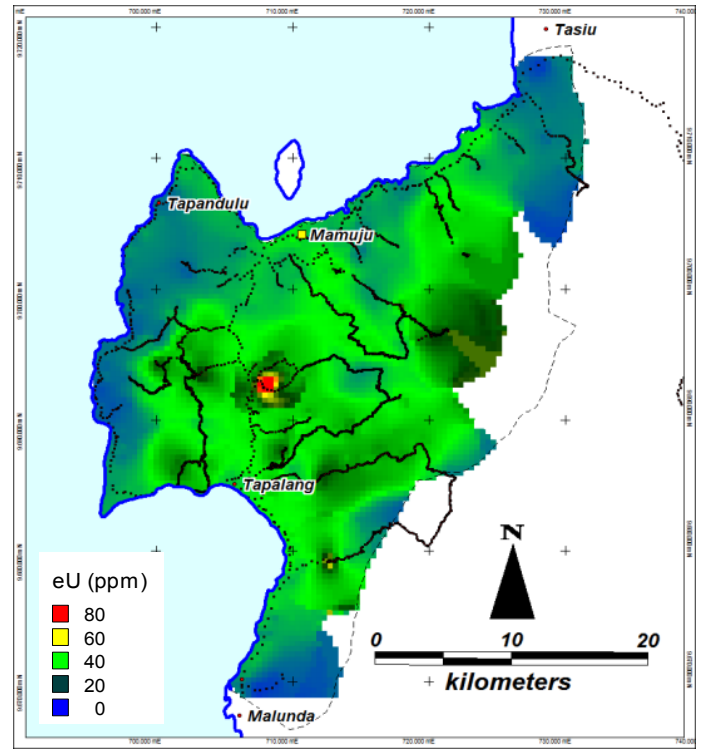

Fig. 6. Radioelement map of Uranium (U). 
Krishnaswami, 1999 in IAEA (2003) [11] stated that thorium can be dissolved in acid solutions and its solubility is enhanced by humic acids. The abundance of thorium in the Earth's crust is low, typically in the range of ppb to ppm with an average of about $12 \mathrm{ppm}$. Thorium is a constituent of the accessory minerals zircon, monazite, allanite and xenotime, apatite and sphene. In general, about 60 years is required to establish radioactive equilibrium in the Th series, and gamma ray activity is thus a good measure of Th concentration. Radiometric map of thorium shows the relatively high thorium anomaly, which is higher than $200 \mathrm{ppm}$ eTh in Pengasaan, Takandeang, and Ahu village.

Besides the radioelement concentration, the radioelement ratio map was also established. According to IAEA (2003) [11] ratios between radioelement concentrations $(\mathrm{Th} / \mathrm{U}, \mathrm{Th} / \mathrm{K}, \mathrm{U} / \mathrm{K})$ are often used to reduce the effect of terrain geometry on the concentration estimates. Anomalous ratios are also often indicative of mineralization and rock alteration.

Further, Shives, 1997 in Wilford et al. (2009) [18] described the use of radioelement ratio for analysis of uranium mineralization. Uranium occurs in two main valence states: $\mathrm{U}^{4+}$ and $\mathrm{U}^{6+}$. The oxidized form $\mathrm{U}^{6+}$ is most common in near-surface conditions and forms complexes with oxygen to create a uranyl ion $\left(\mathrm{UO}_{2}{ }^{2+}\right)$. The solubility of uranium is favoured by oxidizing conditions and acid groundwater. Under reducing conditions, the $\mathrm{U}^{4+}$ form is contained in insoluble minerals. Weathering and alteration associated with hydrothermal systems can preferentially concentrate uranium compared to thorium. In order to analyze thorium mineralization, Shives, 1997 in Wilford et al. (2009) [18] described that thorium has a single valence $\left(4^{+}\right)$in near-surface environments and so its mobility does not alter under changing redox conditions. Importantly, thorium, unlike potassium and uranium, is not usually affected to the same degree by weathering and alteration processes.

Map of $\mathrm{Th} / \mathrm{K}$ ratio reflect the area of thorium mineralization, from field investigation it is interpreted as the later process of alteration of supergene enrichment. The areas of high $\mathrm{Th} / \mathrm{K}$ among others are Ahu, Takandeang, and Taan village (Fig. 8a). Th/U ratio map delineate more detailed on the area of supergene enrichment. As described above, the radioelement mobility of $\mathrm{U}$ is much higher than Th, as it is the case in the soil weathering profile. On aspect which also very important is to analyze and explore further on where is the uranium precipitated after it leached by groundwater. The area of high $\mathrm{Th} / \mathrm{U}$ ratio identified in Ahu, Takandeang, Taan, and Binanga (Fig. 8b). The U/K ratio map delineates the area of possible uranium alteration and precipitation, it is as guide for the next uranium exploration program (Fig. 8c).

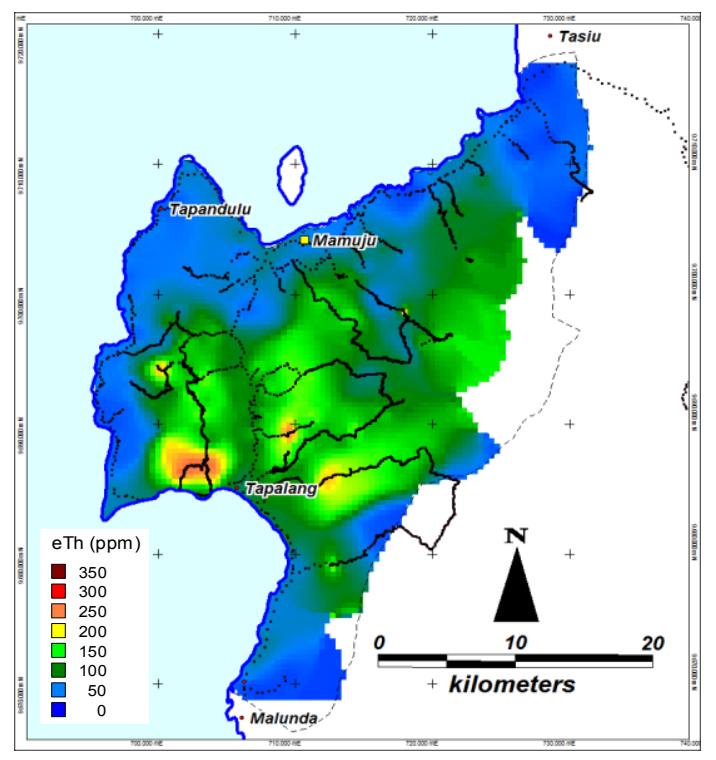

Fig. 7. Radioelement map of Thorium (Th).

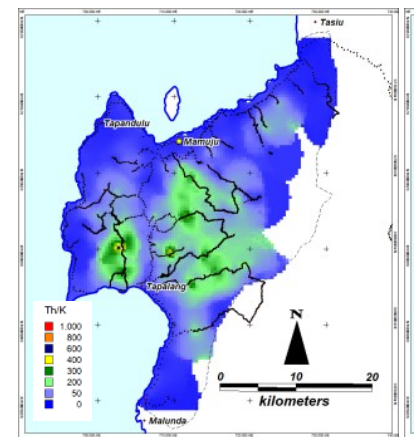

(a)

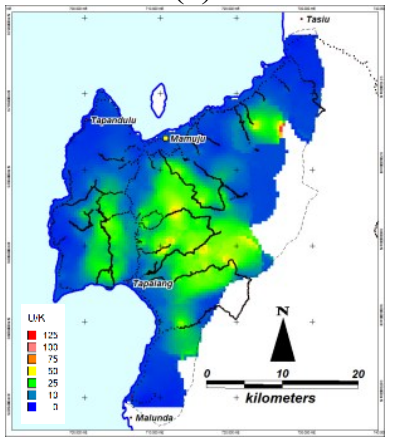

(c)
Fig. 8. Radioelement ratio map (a) $\mathrm{Th} / \mathrm{K}$, (b) $\mathrm{Th} / \mathrm{U}$ and (c) $\mathrm{U} / \mathrm{K}$.

\section{Radiation dose rate map}

The radiation dose rate map useful to delineate the area of NORM anomaly. From view point of radiometric anomaly for radioactive mineral exploration, the number of $400 \mathrm{nSv} / \mathrm{h}$ can be defined locally as radiation background, whereas the anomaly of two or three times (Mitchell, 2007) [15] 
or $800-1,200$ can be defined as anomaly area. Ahu, Takandeang, Botteng, Pengasaan, Tande-Tande, and Mamunyu is the anomaly area in Mamuju (Fig. 9a).

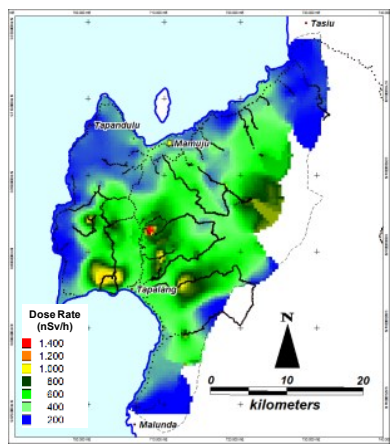

Fig. 9a. Radiation dose rate map.

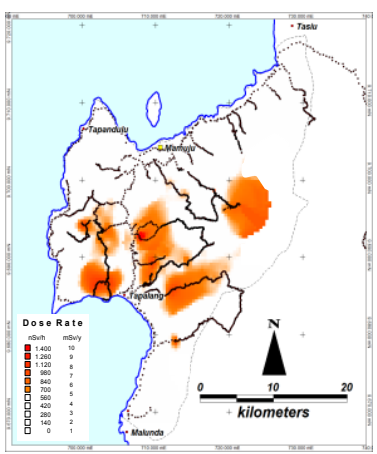

Fig. 9b. Radiation dose rate map of higher than $5 \mathrm{mSv} / \mathrm{y}$.
El-Sadek et al. (2002) [7] describe the scientists and medical doctors from international agencies responsible for radiation protection throughout the world have set an annual radiation dose-equivalent of $5 \mathrm{mSv}$ as a safe maximum dose for a member of the general public. The International Commission of Radiological Protection (ICRP) also has recommended that no individual should receive more than 5000 millirems year $(50 \mathrm{mSv} /$ year) from all natural and artificial radiation sources in his or her environment. In order to have the preliminary assessment of annual dose that can be received by inhabitant, then the unit of $\mathrm{nSv} / \mathrm{h}$ converted to $\mathrm{mSv} / \mathrm{y}$ using the number of occupancy factor of $80 \%(7000 \mathrm{~h} /$ year $)$, refer to Vanmarcke (2000) [19] and Colgan et al. (2008) [4]. The result is the map shows the higher than $5 \mathrm{mSv} / \mathrm{y}$ of radiation dose rate (Fig. 9b). Further attention should be made to Takandeang, Tande-Tande and Botteng due to its dwelling inhabitant, while in Ahu, Pengasaan, and Mamunyu, the area of high dose rate did not used for settlement instead of forest and garden.

\section{CONCLUSION}

Mamuju has high radiation dose rate due to its Naturally Occurring Radioactive Material. The high NORM has been identified in the area of Geological Formation of Adang Volcanic. The formation composed by feldsphatoid lava rock, pyroclastic, tuffities, and granite. The radiometric mapping in Mamuju yield information regarding radioelement concentration in rock and soil. Map of potassium, thorium,uranium, and dose rate has generated, and as an addition the ratio map of $\mathrm{Th} / \mathrm{K}, \mathrm{U} / \mathrm{K}$, and $\mathrm{Th} / \mathrm{U}$ has also generated for analysis the anomaly area based on mobility principle of radioelement. Based on the resulted regional radiometric, the area with high radiation dose rate which is defined as $700 \mathrm{nSv} / \mathrm{h}$ refer to annual dose rate $5 \mathrm{mSv} / \mathrm{y}$ can be delineated,which is Ahu, Takandeang, Botteng, Pengasaan, Tande-Tande, and Mamunyu village.

\section{REFERENCES}

1. A.N. Amadi, N.O. Okoye, P.I. Olasehinde et al., Journal of Geography and Geology 4 (1) (2012) 243

2. E.A. Bahiru, Inter-Relationship between Lithology and Structure and its Control on Gold Mineralization in Buhweju Area, SW of Uganda Thesis, University of Twente (2011).

3. N.E. Bassey and J.M. Ishaka, Journal of Earth Science and Geotechnical Engineering 2 (1) (2012) 39.

4. P.A. Colgan, C. Organo, C. Hone et al., Radiation Doses Received by the Irish Population, Radiation Protection Institute of Ireland. Dublin, Ireland (2008) 20.

5. H. Coetzee and J. Larkin, Application of the Airborne Radiometric Method in Radiation Protection, $11^{\text {th }}$ Saga Biennal Technical Meeting and Exhibition (2009) 453.

6. E.L. Dantas, A.M. Silva, T. Almeida et al., Old Geophysical Data Applied To Modern Geological Mapping Problems: A Case-Study In The Seridó Belt, NE Brazil, Revista Brasileira De Geociencias, Revista Brasileira de Geoscience, Vol. 33 (2003).

7. M.A. El-Sadek, A.A. Ammarand A.M. Sabry, The Arabian Journal for Science and Engineering 27 (2A) (2002) 144.

8. E. Elawadi, A. Ammar and A. Elsirafy, Mapping Surface Geology Using Airborne Gamma-Ray Spectrometric Survey Data - A Case Study, Nuclear Materials Authority of Egypt, Airborne Exploration Dept, Egypt (2008) 1.

9. Anonymous, Radiometric Map of Australia $1^{\text {st }}$ ed., Government of Australia - Australia Geoscience, Australia (2009).

10. E.R. Graaf, R.L. Koomans, J. Limburg et al., Appl. Radiat. Isot. 65 (2007) 619.

11. Anonymous, Guidelines for Radioelement Mapping Using Gamma-ray Spectrometry Data, IAEA-TECDOC-1363, IAEA (2003).

12. Anonymous, Extent of Environmental Contamination by Naturally Occurring 
Radioactive Material (NORM) and Technological Options for Mitigation, TRS-419, IAEA (2003).

13. Anonymous, The Use of Gamma Ray Data to Define the Natural Radiation Environment, IAEA-TECDOC-566, IAEA (1990).

14. D. Iskandar, Syarbaini, Kusdiana et al., Map of Environmental Gamma Dose Rate of Indonesian. PTKMR-BATAN, Unpublished (2007).

15. M. Mitchell, A Prospector Guide To Uranium Deposits in Newfoundland and Labrador. Geological Survey of Newfoundland and Labrador, Canada (2007) 15.
16. N. Ratman and S. Atmawinata, Geological Map of the Mamuju Quadrangle, Sulawesi, Geological Research and Development Center, Bandung (1993).

17. J.C. Thouret, Volcanic Geomorphology - an Overview, Earth-Science Reviews 471999 95131, Elsevier Science B.V. (1999) 96.

18. J. Wilford, L. Worraland and B. Minty, Radiometric Map of Australia Provides New Insights Into Uranium Prospectivity, Government of Australia - Australia Geoscience, Australia (2009) 1.

19. H. Vanmarck, Part on Natural Radioactivity, UNSCEAR 2000: Sources of Ionizing Radiation, Belgium (2000) 3 . 